$\overline{\text { 技 街 }}$

\title{
わが国における製茶産業の現状と問題点 $*$
}

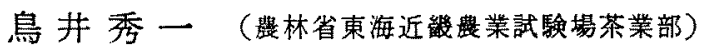

わが国に拈ける慗茶の生産は，世界中でも中国に次いで古い歴史をもっている，それは仏教の伝来とともに， 大陸に渡った留学僧が䚻朝に際して製茶や種子をるたらし, 特に 12 世紀末, 栄西禅師が宋より持参した茶種子 が各地にひろがり，今日有名になっている茶産地の源をなしているすのと厷えられる。

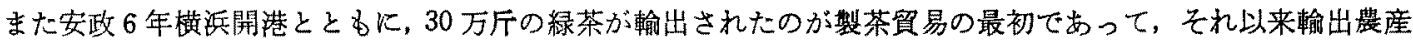
物の重要な位置を占めてきている，しかしその間決して順調に発展の一途をたどったわけでなく，時に盛衰を燥

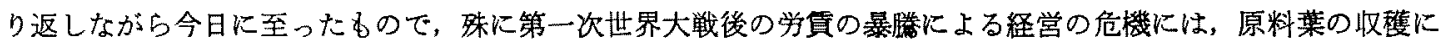
摘採鉄を使用し，またそれまで焙柜で手揉み製造を行っていたものに慗茶機械を導入して，製造の能率化をはか り生産費の低減に成功したのである。

そして第二次大戦前（昭和 15）には，茶園面積 4 万町歩, 産額 1550 万貫, 輸出額 5000 万ポンドに羍したの であるが，戦争勃発とともに食糧作物への転换，肥料・燃料等の生産資材及び労力の不足のため，茶園は $2 / 3 ，$ 生産は $1 / 3$ K激减し，世界各地 66 力国に及んだ輸出仕向地を全く失5に至った. しかし䅂戦後はまた輸入食粗 の見返り品としていち早く貿易に返り吅き, その後茶業者の愿命の努力によって, 戦時中荒廃に帰した茶園の回 復と, 更に進んでは新植茶園の増反を図り, 最近（昭和 29）は茶園面積 3.6 万町歩, 生産額 1800 万貫となつ て，産額は戦前を绫駕するに至つた。

わが国では生産される製茶は主として緑茶であって, 生産額の扰よそ $1 / 3$ は貿易品として海外に輸出される. したがって，貿易事情の盛衰は直ちに量的にも質的にも整茶生産の面に反映してくる. 従来わが国の輸出茶の仕 向地は北米合衆国を最大の顧客としたが，今次大戦による輸出の杜絶の間に，彼地の喈好の変化によって往年の 活況なく，今日では北阿諸国に輪出の主力が注がれ，ここに新たに再開された中共の輸出茶と消費市場を争うこ ととなつたのである。しかしこの国家管理の下に行われる良質な中共茶と対抗することは，日本茶として前途は 決して楽観を許さす，慗茶産業に関する研究・生産・政策の3者の更に緊密な連盽を必要とすること，今日ょり 急なるものはないと痛感する次第である。

\section{緑 萊}

原料の生座

整茶の品質はその原料となる岽葉の性質によって，ほとんど決定されるとみなして差支えない、製茶工程では 原料を配合することもなく，また他物を添加することる許されてないので，製造操作の過誤さえなければ，原料 の良否が直ちに製品の優少となって現われる．それは緑茶製造においては，その第一工程の加熱（蒸熱をた沬鉒 炒)によって酸化酵素の作用を止めてしまった後は、乾燥と整形という製造原理としては比較的簡単な操作でるる ために，茶葉の成分は紅茶の場合のよ５大大きな変化を受けることるなく製品の中に含まれているからである．

それで優良均質な原料葉を得ることが，假良整茶を生産する第一要因であるために，これ音で長年にわたって 品種改良の研究が行われ，既に優良品種として登録せられたものは15 品種に及んでいる，近年茶農家は競つて

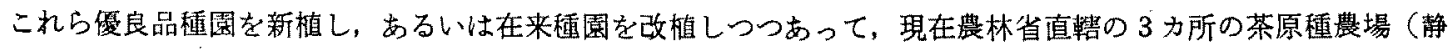
岡県金谷町，奈良市，鹿児島県知覧町)で生産される種苗でなお怙たしく不足を感ずる状態であるが,昭和 29 年 1 月の調査では緑茶用品種園 1012.8 町歩に及んでいる.

次に原料の生産に関して重要なことは生産費の問題である. 何物によらず良質にして席価ということは製造上 の理想であるが，殊に輸出品としての製茶の場合，仕向地（主として北阿諸国）の民度や経済水準を考えると， 輸出茶の価額が貿易の消長に鋭敏に影響する，製茶価額の約 70\% は原料費が占め，また原料費の中では労力費 と肥料費がそれぞれ $1 / 3$ を占めているが，労力費には自家学力をる見込んであるから，実際の支出は肥料費が最

* Recent Status and Some Problems of Tea Industry in Japan.

By Hideichi ToRII (Tôkai-Kinki National Agricultural Experiment Station, Tea Division) 
も大きい，熊本・宮崎・高知等の山地では野生の茶の葉を原料とする所もあり，また中国の茶樹もほとえど無施 肥の状態であるようであるが，わが国では多肥集䄪栽培の様式でないと䅅営は成り立たない，したがって，わが 国の茶業経営では合理的な施肥を行うことが大切である，長年にわたり各地に括ける肥料試験の結果も，茶樹が 永年作物である関係で，的確な数字を握みがたく，収檴物として篹取される肥料成分より推算して一応施肥基準 をN 7 貫，P及びKを3.5 貫と定めているが，実際農家ではこれより滛かに多最施用している所が多い，殊に玉 露・碾茶等の高般茶の産地では年 1 回の摘採（静岡では煎茶は年 $3 \sim 4$ 回）にるかかわらず反当 N 20 貫, 甚だし いものは 65 貫も施肥する状態である.今後あらゆる条件の下における施肥効率の詳しい試験の施行されること が望まれる，な和以前は茶園肥料は有機質肥料を多く用いていたが，現在はほとんど硫安・硝安・尿素・過石一 その他化成肥料等の化学肥料となったためか，最近各地て $\mathrm{Mn}, \mathrm{Mg}, \mathrm{Zn}$ 等の微量要素の欠乏症状が出始めてい るのではないかと疑われるるのが現われてきた。これも今後の一研究題目として採り上げられるものであろろ.

次に問題となるのは原料となる茶葉の成就度であつて，熱帯地方のように茶樹が年中絶えず伸長を続けている 処では，製茶原料として摘採適期に達した茶芽だけを拾い摘みしながら管理下の茶園を順次擗採して超る方法が とられるので，季節による慗品の品質に差はあっても，おまりに硬化した茶葉を原料とすることがないので，同 じ季節では比較的均質な慗品が得られる。しかしわが国では莱樹の春の芽はある程度生長すると芯场が開いて伸 育が止り，次にこの新梢の腋芽が伸びて夏茶の原料を供給するので, 春の芽は一番茶として全部摘み取り, 改め て二番茶の芽を伸ばすような栽培方法を採っている.したがって一番茶整造期間の $2 \sim 3$ 週間の間に春の芽は全 部原料として摘み取られるので，同じ茶期内でも初期と末期では茶葉の性質が变り，ひいては製茶品質にる大差 がある. 特に末期の頃, 茶葉の芯芽が開いてからは, 茶葉は急速に硬化して製茶品質すひどく悪化する.

しかし一方収量を考えると，茶芽が成熟して硬化するにつれ茅重が增し，したがって収量も急激に增加する. 戦後しばらくは，とにかく茶でありさえすれば売れたため下級茶が割高に取引され，茶農家は品質を度外視して， なるべく茶葉を硬化させて反収の增加を図った。そしてこの習慣がなお今日に及んで制茶の品質を落し, 輸出茶 はこれがために前途骨虑せられる状態泣ち至っている.

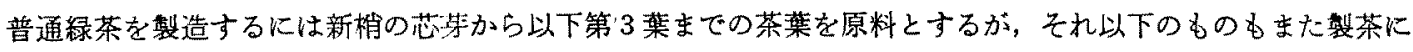
することはできる．しかし葉位の下るに従って製茶品質は下落するし，茶葉の熟度が進めばこれまた品質は低下 する.この関倸は，古来緑茶の品質は全空素含有量でかなりよく判定できるとい5成續から，茶葉の全安素の定 量値を見れば直ちに了解できる。

このよ5に製茶原料の対象となる茶葉には一応の基準はあるが，慗茶の市況によって摘採位置を下げるとか， 摘採期日を崌らせるとかすれば，収量にも品質にも直ちに大幅の動きがみられるので，この点は果実や㯖子を収 瓁する他の多くの作物とは著しく異なる点である. そして今日では茶葉の收嚄は大部分摘採鉄で刚り取る方式に なっているので，昔の手摘みの頃よりる10 倍以上る能率化されたが，その反面手摘みのよ5に揃つた原料が得 られず，古葉や木茎の混入することは避けられない。これらは荒茶の製造が終った後，再製工程で除去されてい るが，これは原料の時に選別する方法を考案したほうが得策ではないかと思われる。

次に玉露及び喽茶のような高解茶は, 伝統を誇る京都を始め, 愛知・静岡等で生産されるが, これらは覆下園 の䒳葉を原料として慗造される，この茶園被覆の技術は古来の経験のままに行われているもので，いま少し生化 学的な根拁が欲しい，その結果ではこの方法は夏茶の品犋改善に貢献する途がありそうである.

\section{製造工程}

国内消費の緑茶の代表的種類は前茶である．今日ではよほど特殊な場合を除いて，すへてて機械製造になってい る. 昔の手揉慜造は蒸した茶葉を木炭で加温した焙炉の上で吅妙な手使いで揉み上げたるのであるが，これでは 1 人 1 日の生産量は僅か $5 \mathrm{~kg}$ にしかならない. 慗茶機珹は明治中頃より考案されてきたが, 実際に広く用いら れ出したのは大正初期からである. 製造の機㳦化と摘採鉄の応用によって生産能率は画期的に增大したが，この 機械も手揉の各操作をそのまま機械的な動作に移し換えたようなもので，蒸機・粗搡機・揉捻機・再乾機・精搡 機・乾燥機の 6 種類の機械が順次使用されている. そしてこれらを十分に使いこなすには予め手揉みの練習が必 要なほど技術の熟練がいる.

このうち揉捻機だけが加熱を要しないもので，他はいずれる個個に熱源を具えているので熱管理上甚だ不経済 である.現用の粗揉譏と再乾機の熱効率を調べてみると，それぞれ 50.6，51.5\% の低率であるが，火炉の構造 
と取り村け方を改良すればもっと熱効率を高め得る見迅はある，然料としては薪・木炭・石炭・コークスなどそ の機械に附属した然烧器に応じて使い分けているが，多忙な製茶作業の間に然料投入のためにしばしば学力をさ かれることは，労働管理の上にも甚だますい方法である．それで近頃は電熱あるいは重油燃焼器に切り換えられ

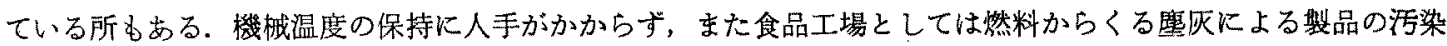
むなくなり一挙両得である.

今日では製茶機城は昔の上5にたた経鈳とカンにだけ頼って製作されることはだんたん少くなり，年年部分的 な要部の改良された新型が製作されているが，それでもな拈従来通りの6 種の機種を頚強に壆守している. 緑茶

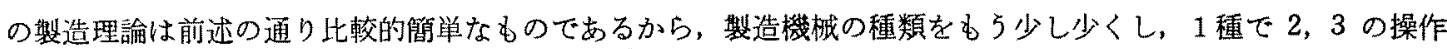
を行わせるよ5にすることは難事でないように考元られる．しかしまだこの点について実用的価值のある装置が できてないのは，一つには製造原料が短時日の間にその性質が相当大きく変るために，機珹の構造や操作をこれ に順応させる上5にしなければなら奴困難性と，も一つには機械が複雑，高価になると現在の茶農家の経済力で は，年間僅かに 20〜45 日くらいしか稼倒しないわのに対しては過重な負担となることである。

次に䎁出茶の主幹をなす緑茶は玉緑茶であつて, これは大正 14 年頃からり連向として生産され出したもので, 今日でも尃ら輸出向である. 煎茶型の緑茶が大量に輸出されていた北米向が振わなくなった現在においては，モ ロッコ,アルゼリア等北阿諸国に輸出されているのがこの種の茶である.

製法はほとんど煎茶と变りはないが，最後に精揉機を用いすと，仕上機で製茶の形状を丸く撚れ形にする．こ れは中国の釜少茶の形状に似かよわせたものであるが，やはり前茶と同じく蒸熱して製造するため鉒炒製とは 風味に異なる点がある．北阿諸国の上5に従来中国の釜炒茶を消費していた方面には，鉒处整茶を輸出するのが いいのはもちろんであるが，釜炒は製造能率が低く生産費が割高となる．これは在来の鉒少茶の炒葉機のような 断続式作業では, 一時に大量の原料を投入することができないので, ぜひとも連続的機構に己るる必要がある.

佐賀・熊本・宮畸等の鉒炒茶の生産地では，近年この方面の研究が進められているが，立だ産地附近の需要を満 たす程度で輸出する活との生産量はない，なお゙鉒少と蒸熱の両作用を加味した炒蒸機の考案も女るが，製茶の形 状が䅭り悪くまだ留品は市場に出ていない．しかしこの点が改良されれば，釜炒より数倍の作業能率があるので 実用化の望はある.

玉粶茶の生産について一番問題になるのは，毎年ある程度まとまった海外需要量が確保できるかどうかであっ て，輸出不振による滞貨は国内に消費の途がないからである．国内需要も海外輸出も同種の茶が用いられるなら ば甚だ好都合なことであるが，慗茶が赀好品である関係上，長年の好みは容易に変えることは困難である．蒸整 玉緑茶は前茶と原料は同じであり，風味も大して变らず，ただ外見が見㓮れないだけで，しかる生産費は少し安 くできるはずであるから，もっと国内需要があってもよさそうに思えるが，生産者の管蒙努力が足りないためな

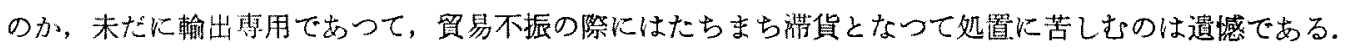

紅

茶

\section{原料の生庢}

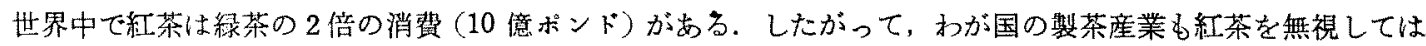
将来の発展性がない，わが国における紅茶製造の歴史は明治初年に始をるが，量産されたのは昭和に入ってから である，従来わが国内で消費される紅茶は，熱带諸国の比較的高級品が輸入されていたために，品質の多る国産

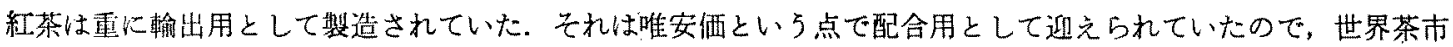
場の相場の变動によってその盛䓂の波は激しかつた.

さきに慗茶の品質は原料茶葉に依存することが大きいと述べたが，殊に紅茶に扣いてはこの関係は決定的であ る. 良質の紅茶の生産にはタンニン含量の多い茶葉が絶対に必要であって，現在作られている紅茶の大多数は夕

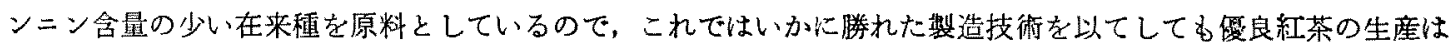
期待できない，茶葉のタンニン量は溨培立地条件にもよるが，根本的には品種の特性と考えられるので，南方産 地のアッサム種の導入が不可久である．ただこの品種は酎寒性が弱く，わが国では九州・四国南部の猫額の無霜 地带に育つに過きないので，昭和 10 年頃から鹿児島県南部に扣いてアッサム種との交配育種が行われ，最近で

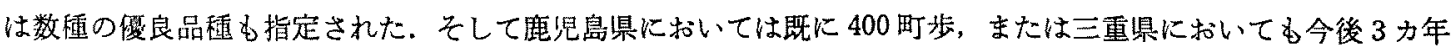
に300町步の品種園の增殖を計画中であり，全国的に将来 1 万町歩，産額 500 万貫を目標として紅茶用品種園が 
次第に桩張せられつつまる。

\section{製造工程}

わが国の紅茶の製法は，かって日乾萎调を行う中国式によったこともあったが，現在はすべてインドーセイロ ン式である.この方法では自然の大気条件の下に打いて，十数時間にわたり茶葉の陰乾菱调を行うため, 紅茶工 場内に広面積の萎调室を必要とする，この建坪を節約するために熱風萎调室や熱風萎调機の試験が行われ，注意 梁く管理された工場では標準製法にあまり棌色のない製品の得られることが分つた，特にわが国の製茶期には梅 雨の影響の避けられ地方もあるので，工場救地の節約だけでなく，不良な天候を克服して作業を進める上にる 更に熱風萎调の研究を行らことが必要である.

次に揉捻は茶葉酸醉の端緒を開き，また製品の形状を決定するのに重要な操作である，従来の紅茶はよく形が 締って何度も前出のきくのが好まれたが，今日ではもっと小形のいわゆるブロークンタイプの需要が多くなって

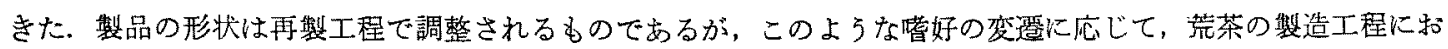
いてブロークンタイプの茶を作るために，搡揄機の探盤の中央に突起を設け，これによって茶葉を細かく引き裂 く方法がインド，七イロンで実施せられて扣り，東海近畿農試茶業部に打いてもこの種の揉捻機を輸入して試験 中であるが，経営規模の小さいわが国の実情では少し巨大に過ぎ（投入量約 $120 \mathrm{~kg}$ ），もっと小型にしないと普 及できないよ5に思われる。

紅茶醱醉の主体は茶タンニンの酵素酸化であって, 製茶化学において最も古くから研究された問題である.こ の際に働く酵素は polyphenoloxidase であり,酸化された茶タンニン化合物が紅茶の浸出液に美しい赤色と特有 な浩味を与えることが知られているが，今日では更に茶タンニンを模成する各のカテキンについて，その変異の 様相と慗茶品質との関係にまて立ち入って研究を進める必要に迫られている。なお茶タンニンは紅茶の水色と滋 味に深い関倸がある外に，最近〉漸で発表されたところによれば、アミ，酸と結合して香気成分を生成するとい われているのは興味ある研究課題である.

\section{むす び}

今日世界の大産茶地带となっている国国は，中共を除きインド，セイロンインドネシアにしてもいずれも最 近までは殖民地であって，践茶産業はこれらの国の農民の極めて安洒な労貢の上に成り立っていたものである. わが国の茶業はこの点に括いて始めから大きなハンディキャップを持つるのとい方る．それで今後日本茶が世界 市場においてこれらの国国の製品と競争するためには，生産費の低下を図ることが最も留意すべきことである。 そのために当面の問題として次の事項が考えられる。

1. 反収の增加：これには品種改良, 施肥己善及び病虫害の防除.

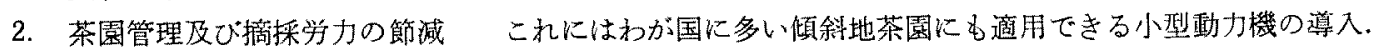

3. 製造機械の改良： 慗造方法の简易化と熱効率の增進.

これらを完遂するためには，まず確りした基磷研究の必要なことはもちろんである。 